\title{
Prevalence of Phytophthora spp. In Citrus Nurseries of Vidarbha Region
}

\author{
R. S. Lad ${ }^{1 *}$, R. M. Gade ${ }^{2}$ and Mina D. Koche ${ }^{3}$ \\ ${ }^{1}$ Department of Plant Pathology, Dr. P.D.K.V., Akola, Maharashtra, India \\ ${ }^{2}$ College of Agriculture, Gadchiroli, Maharashtra, India \\ ${ }^{3}$ Shri. Shivaji Agriculture College, Amravati, Maharashtra, India \\ *Corresponding author
}

\section{A B S T R A C T}

\begin{tabular}{|l|}
\hline Ke y w o r d s \\
$\begin{array}{l}\text { Phytophthora, } \\
\text { Nursery, Survey, } \\
\text { Morphology, Citrus }\end{array}$ \\
\hline Article Info \\
\hline $\begin{array}{l}\text { Accepted: } \\
\text { 26 July 2020 } \\
\text { Available Online: } \\
\text { 10 August } 2020\end{array}$ \\
\hline
\end{tabular}

\section{Introduction}

Citrus occupies the position of most remunerative fruit crops of India, having it own niche in the international trade and world finance. Nagpur mandarin, Sweet orange and Acid lime are the three important species of citrus having international acceptance. This is the second largest industry in India and third largest in production. Citrus is primarily grown in Andhra Pradesh, Maharashtra, Punjab, Karnataka, Uttaranchal, Bihar, Orissa, Assam and Gujarat (Lakshmi et al, 2014).
Phytophthora disease has been identified as one of the major causes of decline in citrus. It causes the most serious and economically important soil borne diseases to citrus crops. In year 2016 and 2017 soil samples were collected from Thirty eight (38) surveyed nurseries during August to November. Three species of Phytophthora viz. P. parasitica, $P$. citrophthora and $P$. palmivora found associated to cause damping off, collar rot and root rot in citrus. In the present studies these three of Phytophthora were isolated by using CMA-PARPH medium from collected soil samples. The occurrence of Phytophthora spp. was recorded in 35 out of 38 surveyed locations, with a range from 3.10 to $24.33 \mathrm{cfu} / \mathrm{g}$ of soil in the year 2016 and 2.33 to $24.99 \mathrm{cfu} / \mathrm{g}$ of soil in year 2017. Pooled data of infected murseries indicate propagules in the range of 2.94 to $24.66 \mathrm{cfu} / \mathrm{g}$ of soil. The morphological characters like mycelium and its appearance, sporangial papillation and their shapes and presence of chlaymadospores of different isolated species were recorded. Presence of chlamydospores was observed only in P. nicotianae var. parasitica which were present as intercalary with oval shape and thick wall. 
Nagpur mandarins face short life span and low productivity because of these three species of Phytophthora (Das et al., 2011). Damping off in citrus seedlings occurred up to 24 per cent due to Phytophthora, thereafter, 5-15 per cent mortality occurred in secondary beds (Naqvi, 2006).

Survey have been undertaken to see the association of Phytophthora spp. in Vidarbha region where nearly $80 \mathrm{~L}$ grafts are being raised for sale every year (Gade, 2012). It is very well known that infected nursery plants are one of the major ways of movement of Phytophthora spp. in orchards.

The soil borne pathogen 'Phytophthora' causes tremendous losses in nurseries and orchards of Nagpur mandarin in Vidarbha region of Maharashtra and all over India is well. Unfortunately, since last 10 years or so, growing Nagpur Mandarin has no longer remained a profitable proposition, as it is being increasingly realized by citrus growers, beside with one or other problems. Nevertheless, the area under Nagpur mandarin has considerably increased mainly due to implementation of the different missions of the central government.

The purpose of current study is to estimate prevalence of Phytophthora spp. in selective citrus nurseries and orchards. An intensive rapid roving survey of nurseries in contributes to assess the present status, distribution of plant pathogens prevalent in particular areas. Such surveys are helpful to characterize local isolates of pathogen.

The survey and current status about availability of disease free planting material in study area is also one of the initial views of this research work. It is generally agreed that the environment is the driving force in the development of epidemics (Hardwick, 1998).

\section{Materials and Methods}

\section{Survey of citrus nursery and collection of soil samples}

An extensive survey of citrus nurseries of Amravati district has been made in year 2016 and 2017 and soil samples were collected from Thirty eight (38) surveyed nurseries during August to November. Samples from particular nursery were collected from rhizosphere and combined to make a composite sample (Naqvi, 1994; Timmer et al., 1989).

\section{Isolation purification of pathogen culture}

Ten gram soil from each sample was diluted in $90 \mathrm{ml}$ water having $0.25 \%$ agar. One $\mathrm{ml}$ aliquot was spread on each of 10 plates of Corn meal agar (CMA-PARPH) selective medium (Kannwischer and Mitchell, 1978). The plates were incubated at $28^{0} \mathrm{C}$ for $2-3$ days and number of colonies of Phytophthora was counted. Soil in the second core was flooded with water, baited with pieces of citrus leaves and placed in the incubator for 48hr (Grimm and Alexander, 1973). The leaves were transferred to petri dishes and examined for the presence of papillate sporangia under compound microscope. Subculture of Phytophthora from infected leaf pieces was easily accomplished by submerging infected leaf pieces in PARPH medium and transferring hyphal tips as they grew in the medium. As soon as the growth of fungus was observed, small portion was transferred to the slants.

\section{Composition of CMA-PARPH selective media (Mitchell et al., 1986)}

Corn meal agar- 17 g/ lit, Pimaricin- 10 mg/ lit, Ampicilin- $250 \mathrm{mg} / \mathrm{lit}$, Refampicin- 10 mg/ lit, PCNB- 100 mg/ lit, Hymexazole- 50 $\mathrm{mg} /$ lit, Distilled water-1000 ml. 


\section{Production of sporangia}

Sporangia are the cells or vessels in which zoospore are formed. Production of sporangia was carried out by the water culture method. A thin layer of sterile distilled water is added to the surface level of discs in Petri plates containing discs of fungus growth removed from culture. Plates are incubated under cool white fluorescent light for 1-3 days and observed daily under the dissecting scope for sporangia.

\section{Morphological Identification and} characterization of the pathogen

Phytophthora spp. was observed under 40X magnification on compound microscope and identified on the basis of their morphological characteristics like mycelium structure, shape of sporangia, presence of chlamydospore etc. and confirmed with the help of CMI publications.

\section{Results and Discussion}

\section{Survey of citrus nurseries}

Citrus nurseries were surveyed in Amravati district of Vidarbha region of Maharashtra. Citrus nurseries in this district were selected during 2016 and 2017 to record prevalence of Phytophthora spp. Soil samples from the nurseries were collected during prevalence of the disease in citrus nursery. Collected samples were subjected for isolation of Phytophthora spp. on selective medium (CMA-PARPH).

The occurrence of Phytophthora spp. was recorded in 35 out of 38 surveyed locations, with a range from 3.10 to $24.33 \mathrm{cfu} / \mathrm{g}$ of soil in the year 2016 and 2.33 to $24.99 \mathrm{cfu} / \mathrm{g}$ of soil in year 2017. Pooled data of infected nurseries indicate propagules in the range of 2.94 to $24.66 \mathrm{cfu} / \mathrm{g}$ of soil (Table 1). Three
Phytophthora spp. viz., Phytophthora nicotianae var. parasitica, $P$. citropthora and $P$. palmivora were isolated from collected samples. $P$. nicotianae var. parasitica was found prominently involved in causing damping off, collar rot and root rot in surveyed citrus nurseries.

The isolation of Phytophthora was done by using leaf bait technique (Grimm and Alexander, 1973) and soil spreading (Kannwisher and Mitchell, 1978) method. Phytophthora was isolated on CMA-PARPH medium (Michell et al., 1986). The use of selective medium was found effective in the detection of Phytophthora when low inoculum was present in the soil (Zitko et al., 1987; Gade, 2009).

For propagule count soil spreading method was used accordingly 35 out of 38 soil samples showed presence of Phytophthora in citrus nurseries (Table 1). Presence of the pathogen may be because of raising of nurseries on same piece of land and to the roadside to attract the customer and free access to enter in to the nursery. Pathogen population can be build up even phytosanitary measures are taken. Ridings et al., (1977) showed that even with strict sanitary practices, recontamination of disinfected areas occurred when it was present near to the nursery.

Gade (2009) and Gade (2012) reported that Phytophthora parasitica is associated with disease in citrus nurseries of Vidarbha in the range of 28 to $46 \mathrm{cfu} / \mathrm{g}$ soil. Present results of association of Phytophthora with citrus rhizosphere confirms the findings of Das et al., (2016) who reported similar results and isolated Phytophthora palmivora, $P$. parasitica and $P$. citrophthora from the soil samples collected from citrus growing areas of Nagpur, Wardha and Amravati districts. 
Table.1 Prevalence of Phytophthora spp. in citrus nurseries of Amravati district

\begin{tabular}{|c|c|c|c|c|c|}
\hline \multirow{2}{*}{$\begin{array}{l}\text { Sr. } \\
\text { No. }\end{array}$} & \multirow[t]{2}{*}{ Location } & \multirow{2}{*}{$\begin{array}{c}\text { GPS } \\
\text { (Latitude/Longitude) }\end{array}$} & \multicolumn{3}{|c|}{ Average cfu / g soil } \\
\hline & & & 2016 & 2017 & Pooled \\
\hline 1 & Badnera & $20.844719 / 77.721848$ & 10.44 & 14.21 & 12.33 \\
\hline 2 & Shivaji Agri. College & $20.950424 / 77.775459$ & 8.88 & 13.10 & 11.00 \\
\hline 3 & Govt. Nursery & $20.948980 / 77.781731$ & 6.77 & 9.0 & 7.89 \\
\hline 4 & Jarud (Hole Nursery) & $21.457016 / 78.228668$ & 12.22 & 21.77 & 17.00 \\
\hline 5 & Tembhurkheda & $21.504112 / 78.215836$ & 11.77 & 14.77 & 13.27 \\
\hline 6 & Warud & $21.496664 / 78.266365$ & 10.11 & 6.88 & 8.50 \\
\hline 7 & Wai mauje (S. ghat) & $21.503023 / 78.268936$ & 4.11 & 2.33 & 3.22 \\
\hline 8 & Wai mauje (S. ghat) B & $21.503023 / 78.268936$ & 5.88 & 5.99 & 5.94 \\
\hline 9 & Tivsa ghat & $21.511379 / 78.271576$ & 00 & 00 & 0.00 \\
\hline 10 & Pimpalsheda A & $21.527672 / 78.262978$ & 10.33 & 7.99 & 9.17 \\
\hline 11 & Pimpalsheda B & $21.526918 / 78.258087$ & 4.22 & 3.66 & 3.94 \\
\hline 12 & Zatamziri A & $21.541759 / 78.237930$ & 8.55 & 2.99 & 5.77 \\
\hline 13 & Zatamziri B & $21.534712 / 78.246094$ & 7.10 & 7.33 & 7.22 \\
\hline 14 & Rawala A & $21.528708 / 78.275536$ & 6.33 & 12.55 & 9.44 \\
\hline 15 & Rawala B & $21.559467 / 78.276146$ & 7.55 & 10.32 & 8.94 \\
\hline 16 & Satnur & $21.566528 / 78.283066$ & 5.33 & 5.88 & 5.61 \\
\hline 17 & Shendurjana ghat (Bhavesh Nursery) & $21.538845 / 78.296150$ & 6.10 & 7.10 & 6.61 \\
\hline 18 & Shendurjana ghat A & $21.521938 / 78.290787$ & 3.10 & 2.77 & 2.94 \\
\hline 19 & Shendurjana ghat B & $21.525549 / 78.295952$ & 00 & 00 & 0.00 \\
\hline 20 & Mauja jamtal & $21.530968 / 78.303642$ & 3.66 & 2.88 & 3.28 \\
\hline 21 & Wai & $21.567837 / 78.335106$ & 4.88 & 7.88 & 6.39 \\
\hline 22 & Jamtal & $21.537741 / 78.308250$ & 6.33 & 2.55 & 4.44 \\
\hline 23 & Shendurjana ghat $\mathrm{C}$ & $21.514324 / 78.297485$ & 4.44 & 5.44 & 4.94 \\
\hline 24 & Malakapur (S. ghat) & $21.508900 / 78.299469$ & 4.77 & 5.99 & 5.39 \\
\hline 25 & Loni A & $21.381285 / 78.174507$ & 10.99 & 13.21 & 12.11 \\
\hline 26 & Loni B & $21.374554 / 78.174927$ & 24.33 & 24.99 & 24.66 \\
\hline 27 & Bargaon & $21.438925 / 78.132545$ & 5.77 & 10.99 & 8.39 \\
\hline 28 & Jarud B & $21.455263 / 78.206528$ & 12.66 & 13.21 & 12.94 \\
\hline 29 & Zolamba & $21.381041 / 78.118736$ & 10.77 & 15.88 & 13.33 \\
\hline 30 & Hiwarkheda A & $21.395351 / 78.069649$ & 9.88 & 11.77 & 10.83 \\
\hline 31 & Hiwarkheda B & $21.407637 / 78.077736$ & 9.10 & 10.66 & 9.89 \\
\hline 32 & Govt. farm Umarkhed & $21.425966 / 78.105476$ & 00 & 00 & 0.00 \\
\hline 33 & Hiwarkheda C & $21.412468 / 78.087799$ & 10.66 & 11.77 & 11.22 \\
\hline 34 & Bhaypur & $21.377542 / 78.054153$ & 6.77 & 8.22 & 7.50 \\
\hline 35 & Govt farm Yerla & $21.335150 / 78.003914$ & 5.10 & 9.66 & 7.39 \\
\hline 36 & Bhumiputra nursery Khed & $21.278652 / 77.862617$ & 16.99 & 10.22 & 13.61 \\
\hline 37 & Govt. nursery Tivsa & $21.093372 / 78.090927$ & 6.44 & 11.00 & 8.72 \\
\hline 38 & Govt. nursery Chandur & $20.816896 / 77.981674$ & 4.88 & 4.66 & 4.78 \\
\hline
\end{tabular}


Table.2 Morphological characteristics of Phytophthora spp.

\begin{tabular}{|c|c|c|c|c|}
\hline \multirow{2}{*}{$\begin{array}{l}\text { Sr. } \\
\text { No. }\end{array}$} & \multirow{2}{*}{ Characters } & \multicolumn{3}{|c|}{ Species } \\
\hline & & $\begin{array}{l}\text { Phytophthora } \\
\text { palmivora }\end{array}$ & $\begin{array}{c}\text { Phytophthora nicotianae } \\
\text { var. parasitica }\end{array}$ & $\begin{array}{l}\text { Phytophthora } \\
\text { citrophthora }\end{array}$ \\
\hline & \multicolumn{4}{|c|}{ Mycelium and chlamydospore } \\
\hline 1 & Mycelium & $\begin{array}{l}\text { Coenocytic, cottony } \\
\text { mycelium }\end{array}$ & $\begin{array}{c}\text { Coenocytic, dense } \\
\text { cottony } \\
\text { Mycelium }\end{array}$ & $\begin{array}{l}\text { Coenocytic hyaline to } \\
\text { slightly brownish }\end{array}$ \\
\hline 2 & Colony colour & $\begin{array}{l}\text { Puffy dull white } \\
\text { with stellate pattern }\end{array}$ & creamy white & $\begin{array}{l}\text { White rosette and slightly } \\
\text { cottony, Pettaloid pattern }\end{array}$ \\
\hline \multirow[t]{2}{*}{3} & Chlamydospore & Not recorded & Intercalary & Not recorded \\
\hline & \multicolumn{4}{|c|}{ Sporangia } \\
\hline 4 & Shape & Mainly ovoid & $\begin{array}{l}\text { Speroid (spherical), } \\
\text { prominent papilla }\end{array}$ & $\begin{array}{l}\text { Varies from spherical, } \\
\text { ovoid }\end{array}$ \\
\hline 5 & Papillation & distinctly pappilate & prominent papilla & Papillate \\
\hline
\end{tabular}

Fig.1 Microphotographs of sporangia of Phytophthora spp.
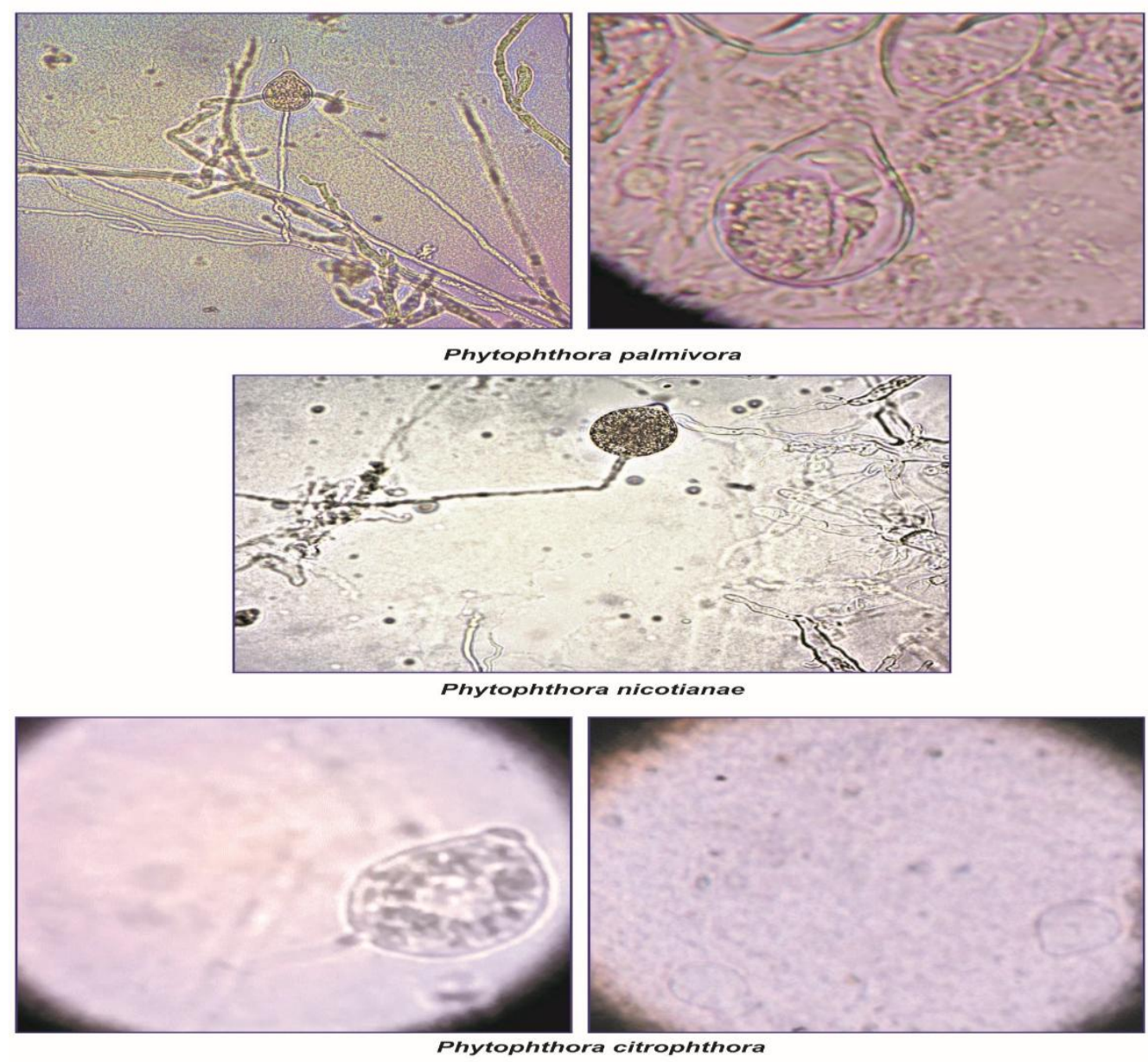
Fig.2 Microphotographs of morphological changes in zoosporangia and release of zoospores from sporangia of Phytophthora spp.
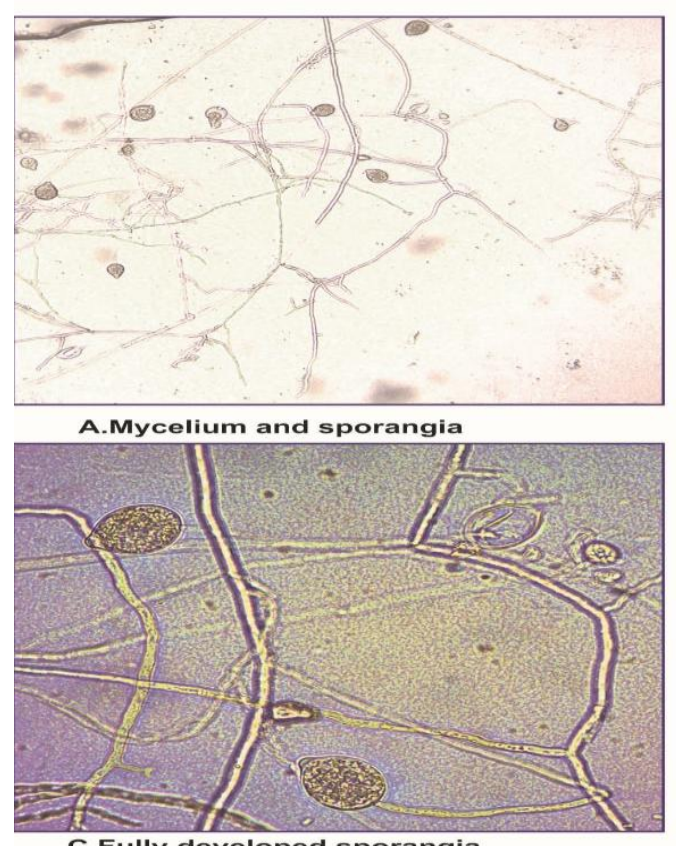

C.Fully developed sporangia

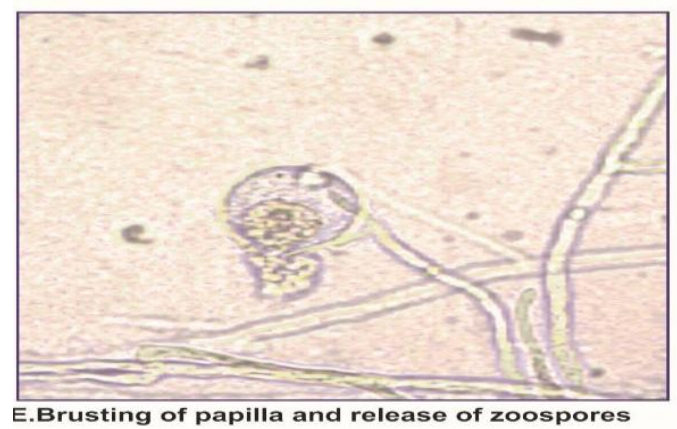

Present results are helpful to show current status of citrus nurseries regarding Phytophthora population and accordingly to plan management strategies in study area on the basis of detected inoculum level present in the soil.

\section{Morphological characteristics of Phytophthora spp.}

In the present studies three Phytophthora spp. viz., Phytophthora palmivora, P. nicotianae var. parasitica and $P$. citrophthora were isolated by using CMA-PARPH medium from collected soil samples from experimental

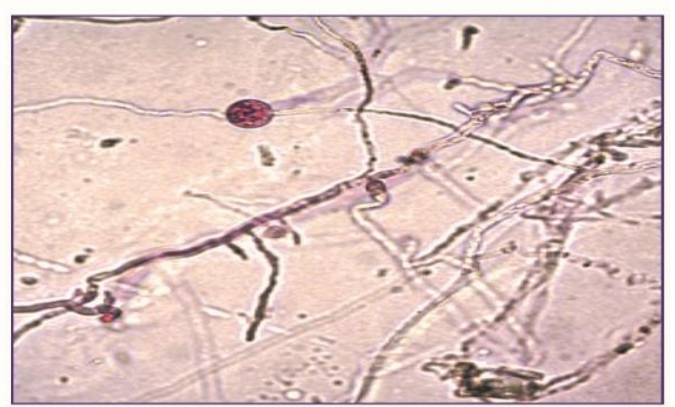

B. Chalmydospore

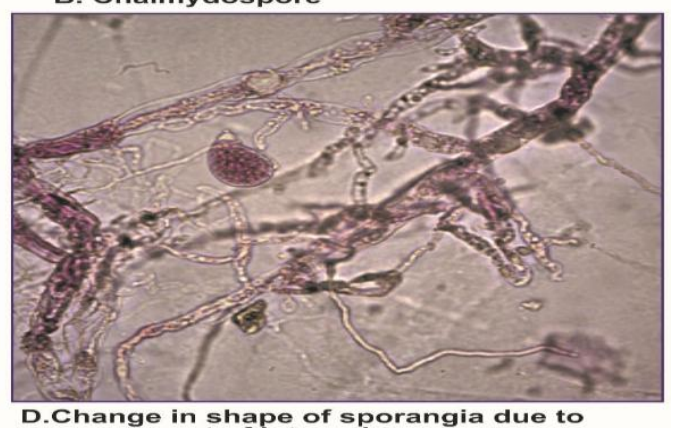

D.Change in shape of sporangia due to
movement of internal zoospores

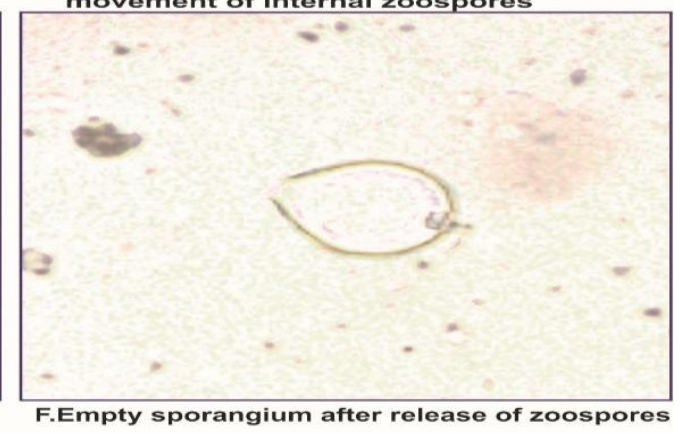

fields. The morphological characters like mycelium and its appearance, sporangial papillation and their shapes and presence of chlaymadospores of different isolated species were recorded.

The results presented in Table 2 showed that $P$. palmivora produced a puffy, stellate pattern whereas, $P$. nicotianae var. parasitica produce dense cottony mycelium having creamy white colony colour whereas, hyaline to slightly brownish mycelium and white rosette to slight cottony colonies with pettaloid pattern were produced by $P$. citrophthora. Coenocytic mycelium was the 
particular characteristic found in all three species. Ovoid sporangia were observed prominently in $P$. palmivora whereas, prominent papilation was observed in $P$. nicotianae var. parasitica and spherical to ovoid sporangia was observed in $P$. citrophthora. Presence of chlamydospores was observed only in $P$. nicotianae var. parasitica which were present as intercalary with oval shape and thick wall (Figure $1 \& 2$ ).

Morphology of Phytophthora has been well determined in past (Brasier and Griffin, 1979). More than 50 species have been identified based on morphological characteristics (Stamps et al., 1990). The observations recorded in respect of mycelium, sporangial shape and papillation are in agreement with the findings of Drenth and Sendall (2001) who reported that, sporangium shape, papillation, presence of chlamydospores are the morphological characters upon which identification of Phytophthora was based and did morphological study of commonly found Phytophthora spp. of southeast Asia. Results were also correlate with the work of Das et al., (2016) who reported that, morphology of $P$. nicotianae isolate produced spheroid sporangium that were non caduceus and papillate, whereas $P$. palmivora isolates produce ovoid papillate sporangia. Gupta et al., (2012) also observed creamy white cultural characters in most of studied $P$. nicotianae isolates.

More diversity was observed in the colony morphology of isolated Phytophthora spp. A different colony patterns were observed in these three species of Phytophthora indicating a high level of morphological diversity within the species. Diverse sporangial shapes and structures observed in various Phytophthora spp. were ovoid to spherical/ globose. These findings are in agreements with Mounde et al., (2012) who studied morphological and cultural characters like colony diameter, size, shape, length breadth ratio of sporangia, hyphae diameter, production of chlamydospores and found differences in these characters of $P$. citrophthora, $P$. nicotianae and $P$. syringae.

\section{Acknowledgments}

The authors are thankful to the Information Technology Research Academy (ITRA), Ministry of Information Technology, GOI, New Delhi for providing fellowship and funding to conduct this research work.

\section{References}

Brasier, C. M. and M. J. Griffin, 1979. Taxonomy of Phytophthora palmivora on cocoa. Trans. Br. Mycol. Soc., 72: 111-143.

Das, A. K., A. Kumar, A. Ingle and S. Nerkar, 2011. Molecular identification of Phytophthora spp. causing citrus decline in Vidarbha region of Maharashtra. Indian Phytopath., 64 (4): 342-345.

Das, A. K., S. Nerkar, A. Kumar and S. Bawage, 2016. Detection, identification and characterization of Phytophthora spp. infecting citrus In. J. of Plant Pathology, 98 (1): 55-69.

Drenth, A. and B. Sendall, 2001. Practical guide to detection and identification of Phytophthora Version 1.0, CRC for Tropical Plant Protection, Brisbane Australia.

Gade, R. M., 2009. Biological and chemical management of Phytophthora root rot/ collar rot in citrus nursery. International Conference on Plant Disease, France, Pp. 245-53.

Gade, R. M., 2012. Biological and chemical management of Phytophthora root rot / collar rot in citrus nursery. The bioscan 7 (4): 631-635. 
Grimm, G. R. and A. F. Alexander, 1973. Citrus leaf pieces as traps for Phytophthora parasitica from soil slurries. Phytopathology, 63: 540-541.

Gupta, S. K., K. Jarial, M. S. Saharan, R. Kaur and B. Saxena, 2012. Morphological and genetic variation among Phytophthora nicotianae var. nicotianae isolates causing fruit rot of bell pepper and their correlation with genetic variability among host genotypes. Indian Phytopath., 65 (1): $38-44$.

Hardwick, 1998. Dispersal of Phytophthora cinnamomi on the island of Hawaii. Phytopathology, 66: 457-460.

Kannwischer, M.E. and K.J. Michell, 1978. The influence of a fungicide on the epidemiology of black shank of tobacco. Phytopathology. 68, 17601765.

Lakshmi, T., V. Gopi, T. Sankar, G. Sarada, L. Lakshmi, K. T. V. Ramana and K. Gopal, 2014. Status of diseases in sweet orange and acid lime orchards in Andhra Pradesh, India. Int. J. Curr. Microbiol. App. Sci., 3 (5): 513-518.

Mitchell, D. J, M. E. Kannwischer-Mitchell and G. A. Zentmyer, 1986. Isolating, identifying and producing inoculum of Phytophthora spp. In: Methods for evaluating pesticides for control of plant pathogens, K.D. Dickey (Eds.), APS press, St. Paul, MN, pp. 312.

Mounde, L. G., E. M. Ateka, A. W. Kihurani, L. Wasilwa, 2012. Morphological characterization and identification of Phytophthora spp. causing citrus gummosis in Kenya. African Journal of Food, Agriculture, Nutrition and
Development, 12 (7): 287-292.

Naqvi, S. A. M. H., 1988. Prevalence of Phytophthora spp. pathogenic to citrus in orange groves of Vidarbha, Maharashtra. Indian J. Mycol. Pl. Pathol., 18 (3): 274-276.

Naqvi, S. A. M. H., 1994. Efficacy of some fungicides in control of Phytophthora disease of Nagpur mandarin in central India. Indian Phytopath., 47 (4): 430434.

Naqvi, S. A. M. H., 2006. Distribution of citrus Phytophthora spp. and mating types pathogenic to citrus in central India. J. Mycol. Pl. Pathol., 36 (1): 4449.

Ridings, W. H., N. C. Schenck, R. R. Snell, W. M. Keen and J. A. Cornell, 1977. Reinvention of Methyl bromide treated soil by soil borne fungi and their subsequent effect on citrus seedling growth. Proc. Fla. State Hort. Soc., 90: 70-74.

Stamps, D. J, G. M. Waterhouse, F. J. Newhook and G. S. Hall, 1990. Revised tabular key to the species of Phytophthora. Mycol. Paper No. 162, CABI International Mycological Institute, Kew, U. K.

Timmer, L. W., S. E. Zitko, H. A. Sandler and J. H. Graham, 1989. Seasonal and spatial analysis of populations of Phytophthora parasitica in citrus orchards in Florida. Plant Dis., 73: 810-813.

Zitko, S. E., L. W. Timmer and W. S. Castle, 1987. Survey of Florida citrus nurseries for Phytophthora spp. Proc. Fla. State Hort. Soc., 100: 82-85.

\section{How to cite this article:}

Lad, R. S., R. M. Gade and Mina D. Koche. 2020. Prevalence of Phytophthora spp. In Citrus Nurseries of Vidarbha Region. Int.J.Curr.Microbiol.App.Sci. 9(08): 3548-3555. doi: https://doi.org/10.20546/ijcmas.2020.908.409 